\title{
Legal Framework as a Core Element of District Cooling Success-The Case of Denmark
}

\author{
Bent Ole Gram Mortensen \\ University of Southern Denmark, Copenhagen, Denmark \\ Email: bom@sam.sdu.dk
}

Received June 2014

\section{Abstract \\ This paper describes the Danish legal framework for district cooling as an example of a model which so far has had limited success. A number of suggestions are analysed and discussed.}

\section{Keywords}

\section{District Heating, District Cooling, Legal Framework}

\section{Introduction}

District cooling is becoming a hot topic. Even in a Nordic context, many buildings have a need for comfort cooling in the interest of the users. In most places, building cooling is done by means of electrically driven compressors installed in the building. Rising energy prices and the general need for energy efficiency, inter alia for climate policy reasons, make the district cooling concept more and more interesting. The term "district cooling" refers to the arrangement where the cooling of a building is handled by centralised units which distribute cooling to multiple buyers through a heating or cooling medium via a grid. District cooling is a collective solution as an alternative to an individual cooling solution.

To simplify a little, district cooling covers two basic concepts. First, a primary solution is where cold water is produced in a facility and distributed through a network to a number of buyers. The central station can use different sources such as low temperatures in groundwater, lake water and seawater(so-called "free cooling"), and secondly energy for cooling can be obtained by utilising the energy in district heating water feeding district heating water to the end-user absorption unit which utilises district heating water to produce cooling water.

The ability to convert district heating to cooling has made the technology particularly interesting to the district heating sector and thus for countries with a large district heating sector, such as the Nordic countries Finland, Sweden and Denmark District Heating Covers a Large Part of the Need for Building Heating in These Three Countries. In Terms of Percentages, in Denmark 61.8\% (2010), Finland 45\% (2009) and Sweden 55\% (2009) [1].

In Finland there has been cooling in Helsinki since 1998, and now it is also used in Turku, Lahti, and Vierumäki. Denmark has not come so far; the supply of district cooling from a major public construction project 
only began in 2009 (in Copenhagen). The most advanced of the three Nordic countries is Sweden, where the first plant was built in 1992. Sweden now has more than 30 plants with a delivery of nearly 700 GWh [2].

From a Chinese perspective, a combination of district heating and district cooling would be a more energyefficient solution, and it would be particularly interesting to examine for those areas in China with hot summers and cold winters. Using a combined district heating and district cooling solution, it would be possible to provide heat through district heating in the winter and in the summer to have cooling from district cooling. In urban areas, the change from individual building heating to a collective district heating solution could also help reduce air pollution problems, not only because of the lower overall consumption of fossil fuels but also because air pollution control is much easier and cheaper for one large chimney than for a thousand small chimneys. Often there will also be long-term cost savings through economies of scale.

District cooling is most interesting in the larger cities. In Denmark, district heating plants in major cities are typically owned by the municipality. The municipal ownership entails a legal requirement and, since 2008, Denmark has had a special District Cooling Act (Act No. 465 of 17 June 2008 on municipal district cooling) which specifically provides a basis for municipal participation in district cooling operations. Thus, district cooling has become a municipal supply activity in Denmark.

The Municipalities are in Denmark the main planning authorities. Energy planning touches upon a number of different legal areas, from planning and environmental laws, to state aid rules and municipal law. In addition, the district cooling concept seems to provide benefits in terms of increased energy efficiency. This article looks at Danish law and the role of the Danish municipalities. This article is part of the research in the Strategic Research Centre for 4th Generation District Heating (4DH), which has received support from the Danish Strategic Research Council. The article is based on a presentation held at the 2014 Conference on Heat Energy (HE 2014), September 12-14, 2014 in Wuhan, China.

It is argued that the Danish legislature could with advantage consider whether municipalities should be allowed to continue to provide loan guarantees for district cooling projects and whether in the future municipal district heating companies should be allowed to operate district cooling activities.

Furthermore, it is argued that municipalities should take a more active role in district cooling operations, for example by considering the possibility of more active planning with respect to new construction.

The implementation of district heating and district cooling solutions, however, requires political tools. Public authorities such as the state and municipality can, of course, introduce such solutions for their own buildings, if there is a sufficient concentration of public buildings in a given area to make this economically profitable. It is more problematic when buildings are privately owned, as legislation is required to force private owners to comply. Furthermore, the setting up of district cooling—like district heating - requires a relatively large initial investment, which can be difficult to get private investors to undertake. One solution could be to let the public authorities, who can afford a long-term investment and devaluation horizon, assume ownership of the district cooling plant, or at least to guarantee loans to do so. In Denmark, we have successfully used this method for district heating. However, it has not been quite so easy with district cooling. This is because different legal frameworks for district cooling have been chosen compared with those for district heating. The following describes the Danish legal framework for district cooling as an example of a model which so far has had limited success.

\section{Who Is Regulated by the Danish District Cooling Act?}

So far, in principle, anyone could establish a district cooling project in Denmark. This is also true in regard to private ownership, including the widely used consumer-owned district heating supply companies.

A problem has arisen in connection with the possibility for the municipalities and district heating companies owned by municipalities to engage in district cooling activities. In contrast to the supply of district heating, there has been no tradition of municipal supply of district cooling in Denmark. The non-statutory rules about what municipalities can deal with financially within municipal authority, which are based on tradition, would require a legal basis before the municipalities could lawfully could establish and operate district cooling systems [3].

The question of whether the Danish municipalities, on the basis of municipal authority, could operate district cooling plants has previously been submitted to the regulatory authorities designated by the state to check whether municipalities comply with the regulatory framework. It is the supervisory practices which have determined the limits of municipal authority and so far the supervising authorities have refused to accept that municipal authority could serve as a basis for municipal operation or guaranteeing of district cooling systems. In a 
decision dated 11 February 2008, the State Administration of the Capital City of Copenhagen indicated that the Copenhagen Municipality could not own a limited liability company that operated a district cooling business. See also State County of North Jutland's letter of 30 November 2005 to Viborg Municipality. Case law in this area is limited.

It has not been possible for municipalities to find a legal basis in the Danish Heat Supply Act (Consolidated Act No. 1184 of 14 December 2011) for dealing with district cooling. It is stated in the Heat Supply Act section 1 subsection 1 that the purpose of the Act includes energy use for heating buildings and hot water supply. Following a literal interpretation, the Act does not regulate energy production or energy supply that has a different purpose.

In the Danish Energy Regulatory Authority's statement of 23 June 2010, the Danish Energy Regulatory Authority ruled that, in its opinion, process heat supply is within the scope of the Heat Supply Act price adjustment clause in section 20 of the Act. However, the Danish Energy Regulatory Authority believes that the legal basis for this is unclear and should be clarified. The decision was based on the fact that the scope of the price regulation provision is not linguistically limited in the same way as the objects clause, since it does not refer to energy use, and the history of price determination shows that all deliveries from those plants are covered by the provision, which in turn can lead to the understanding that the supply of process heat is also covered by the provision. Thus, an ambiguity has been created about the legal position in relation to district cooling from district heating systems, which is not covered by the District Cooling Act.

With the District Cooling Act, an explicit legal basis now exists for the Danish municipalities to own and operate a district cooling company. But the existing legal basis is not without its limitations, which are discussed below.

\section{The Purpose of the District Cooling Act}

In the District Cooling Act it is stated that it has the specific purpose of promoting energy efficiency. This is clear from section 1 of the Act, which states that the establishment and operation occur "in order to promote energy-efficient cooling of buildings". Likewise, it is stated in the explanatory notes of Bill L 127 as delivered on 28 March 2008 that the purpose is "to promote energy-efficient cooling of buildings". Increased energy efficiency reduces the use of limited resources such as fossil fuels, and boosts security of supply, reduces emissions of carbon dioxide (Carbon dioxide, $\mathrm{CO}_{2}$ ), and air pollution.

In connection with the enactment of the law, there appeared to be an expectation of an increased need for cooling, due in part to increased use of electrical appliances. The explanatory notes state that this is the actors' expectation. The Act was an implementation of the energy policy agreement from 2008 between the Government and the majority of the opposition parties on the Danish energy policy in the years 2008-2011.

\section{The Primary and Secondary Sources}

It follows from District Cooling Act section 2 that production will mainly be by means of district heating or free cooling. This provides the municipal district cooling companies with the legal basis to be a secondary part of production from other sources, which in practice means utilising a compressor.

It also follows from the explanatory notes that part of the cooling load in a district cooling plant can be covered by "a large compressor unit which can be more efficient than the smaller units of individual customers". Furthermore, no distinction is made in the comments between free cooling which can be directly utilised and free cooling as utilised by a central compressor connected to seawater or groundwater, which can work more efficiently than a decentralised compressor that is air-cooled. It is not entirely clear whether a central compressor cooled by seawater or groundwater should be regarded as free cooling or as a source which in accordance with section 2 may not be the primary source of cooling.

It is not clear from the legislative text or notes how large a proportion can be produced using the compressor. When there is talk of a primary part, it may generally be the case that more than $50 \%$ is produced as free cooling or district heating. It would be natural to consider the requirement over a year, given that cooling needs and the available resources alter with the seasons.

Compared to the typical individual solution, district cooling has a number of advantages. For example, the total cooling effect is reduced, because the maximum capacity requirements will be less than the sum of the maximum needs of all the individual plants. Besides, it is possible to harness the advantages of an optimal com- 
bination of free cooling, district heating based cooling and electrically driven compressors.

The financial benefit often lies in the combination. In a straightforward absorption solution, it will be a challenge to recoup building costs, as operating savings are limited by the number of full load hours. For a comfort cooling plant in Denmark, these are often less than 1000 hours per year. In places with more hot summers the numbers of full load hours will be bigger.

There will also be synergies with district heat based cooling. At the time of the year when the need for heating buildings is the least and there is the greatest need for cooling, district heating plants will naturally have an overcapacity. There will be some locations with an excess of heat which, in the absence of other possible use, must be cooled, e.g. example associated with waste incinerators and surplus industrial heat.

Expectations for increased energy efficiency should be seen against the background that the typical cooling solution consists of one or more electrically driven compressors - this is typically done by air-cooling. Other solutions, including individual free cooling, are also seen.

Absorption cooling in itself is not very energy efficient and, considered in isolation, is less energy efficient than traditional electric air conditioning based on a compressor if the applied heat is produced in a boiler. If, however, there is excess heat that would otherwise go to waste, absorption cooling would be more energy efficient.

Other benefits that are not related to energy efficiency include less of a noise problem , centralised service and thus fewer operating personnel for the building owner or tenant, space savings in the building and fewer environmental problems of the type that otherwise may be linked to air coolers.

\section{A Collective Solution}

In relation to a central solution, a local authority is hardly legally able to establish a district cooling plant for the sake of only one end-user. That can scarcely be accommodated within the understanding of the tasks that a municipality can be involved with. It will most likely not be illegal to start with a single plant. However, based on the principle of equal treatment, other potential buyers must be able join the system, if technically possible.

\section{Ownership of District Heating Company}

The District Cooling Act section 1 states the premise that the municipality wholly or partly owns a district heating business. In contrast, the Act provides no legal basis for municipalities which do not own a district heating company to operate a district cooling plant. The explanatory notes do not make it clear why it was necessary to exclude municipalities which do not own a district heating company from being involved with a district cooling company. This may be a manifestation of a general desire only to extend by the minimum possible the opportunity for municipalities to engage in economic activity. There may also be an assumption that the expertise associated with the district heating business, which is particularly relevant for district cooling companies, depends in part on synergies between district heating and district cooling.

\section{Commercial Terms}

It is a requirement of the District Cooling Act section 3 that municipalities operating a district cooling company should do so on "commercial terms". It follows from the general comments on the Bill (127/2008) that municipalities "providing capital for a district cooling company must do so under conditions similar to conditions that a private market investor would have asked. This means, for instance, an interest rate should be calculated that reflects the risk associated with the activity". Funds used later from other municipality businesses should also be made available on commercial terms.

The requirement for commercial conditions seems to be related to the market economy investor principle, known from EU law. The aim is to avoid distortion of competition in the market. The requirement for use of commercial terms is aimed at preventing the funds from public monopolies to be used to cross-subsidise a district cooling company, or for a district cooling company to be supported by public funds. This is consistent with the general assumption that it is anti-competitive to cross-subsidise from a monopoly area to a competitive field.

There is no requirement that the district cooling price must be financially self-supporting. That is otherwise the usual way in the municipal area of supply in Denmark [4]. Nor does the District Cooling Act establish special monopoly pricing mechanisms. District cooling should be considered a fully competitive activity, and there 
is generally freedom of contract between the parties.

In are mote district cooling company operated in connection with a district heating company, the principle of breaking even may apply to the district heating company, and there must not be a cross-subsidy element in pricing. The price of the output, such as the municipal district heating supply for district cooling company, will be subject to the regular price regulation in the Heat Supply Act chapter 4.It will be possible to establish a tariff for district cooling customers, but this should at least be cost-oriented, so that district heating customers are not burdened financially by the increased sales of heat that go to district cooling. District heating supply may generally benefit from better utilisation of capacity and by being able to sell the amount of surplus heat.

\section{Unbundling and Financing}

It is not necessarily without financial risk to operate a district cooling business. It is a matter of policy that district heating consumers are not exposed to any financial risk. The municipality's taxpayers may also suffer losses as a result of a municipal commitment to district cooling activities.

The District Cooling Act section 3 requires the placement of district cooling business in the form of a limited liability company in connection with the establishment of the municipal district cooling company. It follows from the specific comments on the Bill section 1 that there must be economic separation from the municipal district heating activities so that district heating consumers are protected against financial risk. However, it is also believed to have been part of its purpose to protect the municipality against losses other than the capital invested.

The requirement is equivalent to that known from municipal power distribution companies' commitment in group (parallel) activities and is referred to as corporate separation or unbundling. With such a corporate form, the risk for the municipality's deposit capital is reduced.

It is not defined what types of limited liability companies may apply. That is for the municipal council to assess. The corporate form could, for example, be a limited company.

The district cooling company must not be involved in activities other than the district cooling business. Here, there is a requirement of legal unbundling in relation to other activities. Under the Heat Supply Act section $23 \mathrm{~m}$ subsection 5, it follows from the provision of the District Cooling Act section 3 that this does not prevent service functions being carried out through an independent service company. In addition, it cannot be assumed that due to the District Cooling Act section 3 a district cooling company is cut off from other activities similar to the lawful ancillary activity and by-production of the municipal authority. There is nothing prohibiting the district cooling company from owning stakes in other companies.

Under the District Cooling Act section 4, a prohibition is established against municipal grants, municipal bonds and municipal guarantees in relation to the municipal district cooling company. The law text does not explicitly address the district cooling company's ability to lend to the municipality.

The law does not regulate the municipality's ability to inject investment capital in to a district cooling company. Under the specific comments on the Bill section 4, it follows that a district cooling company can be "financed by subordinated loan capital and by foreign capital". The amount of investment capital is not regulated, but the amount will be subject to the general requirements on the provision of district cooling on commercial terms, in accordance with the above. A municipality may therefore not inject more capital into a district cooling company than is economically justified; see also the municipal law principle that municipalities must act in an economically justifiable manner. The principle of economic viability also implies that, when depositing funds in the municipal district cooling company, the municipality should have a reasonable expectation of achieving returns that are normal for the type of business.

Municipal guarantees have been and are quite common in the Danish supply sector. Other things being equal, a local warranty allows the opportunity to borrow at a lower interest rate, and guarantees have helped to carry many district heating projects through financially. One might ask whether the inability to provide municipal guarantees for district cooling projects in effect makes the funding for many district cooling projects impossible. It may be difficult to get municipalities to provide deposit capital, as the project has to compete with other municipal investment needs in more traditional areas. This will undoubtedly be a challenge for municipal projects. On the other hand, it can be seen as a logical consequence of the district cooling company having to be operated on a commercial basis. However, it does not seem very appropriate to give municipalities the power to operate district cooling as a municipal utility and then prohibit the use of instruments that have helped to make other 
municipal utility areas, such as the district heating system, a success.

It is possible to have a district cooling company as a part of a group structure with electricity and heat supply activities. This allows district cooling activities to take advantage of the common options for loans in the utilities group. Similarly, service functions, as stated above, are placed in a service company.

The municipal district cooling company will be subject to the overdraft rule in the borrowing notice (Order No. 1238 of 15 December 2011 on municipal borrowing and granting guarantees, etc.), in compliance with section 9, subsection 2. According to the overdraft rule, the municipal corporations' overdraft may not exceed DKK125 per citizen. However, the municipal district cooling company can borrow without this affecting the municipality's borrowing limit.

\section{Project Approval}

The District Cooling Act section 5 establishes a requirement for project approval. The authorisation requirement also applies to major changes in existing facilities. The municipalities are entrusted with the role of certification authority. This concept seems to have been taken from the district heating area, where the municipality must also give regulatory approval to projects.

The purpose of the project approval is to ensure that the statutory purpose of promoting energy efficient cooling of buildings is realised in the individual projects. Actually, a planning obligation for the municipalities of the district cooling area is not specified, unlike for district heating [5]. However, it is not prohibited for municipalities to include district cooling in the heat planning or in general energy planning.

Only district cooling projects that contribute to more energy-efficient cooling than individual cooling are acceptable. A district cooling project application must contain supporting evidence. It is not clear from the comments to what extent district cooling plants can be based on large heat pumps which are used to produce heat in winter and for cooling in summer, as we see, for example, in Sweden and Finland. It will hardly be contrary to the purpose of the Act to establish such facilities, and it must be assumed that efficiency gains in both district heating plant and building cooling may be involved in the determination of whether a facility may be authorised. Overall, the observations must be interpreted as meaning that establishment is covered when it is substantially more energy efficient than conventional systems. The Minister may lay down rules on the processing of project applications. This authorisation has not yet been utilised.

The District Cooling Act contains no provision requiring the state (represented by the responsible minister) to provide that in exceptional cases the authorisation is granted by the Minister (call in-power) or that approval in specific cases requires the Minister's consent.

The Heat Supply Act regulates the use of mandatory connection; this is not transferred to the District Cooling Act. This has the consequence that mandatory connection cannot be imposed on existing buildings. In the heat supply sector (district heating and natural gas), it can be done with 9 years' notice, cf. Section 10 of the connection notice (Order No. 690 of 21 June 2011 on connection etc. for district heating systems). By contrast, municipalities could impose mandatory connection on new buildings under the general provision in section 15 subsection 1, no. 11 of the Planning Act that local plans may provide for "the provision of or connection to public facilities inside or outside the territory covered by the plan as a condition for entry into service of a new building”. This provision is also likely to apply to district cooling plants. This will allow the municipality, in a local area plan, to impose mandatory connection for new buildings, but not for existing buildings.

\section{Concluding Remarks}

Promoting energy efficiency is the District Cooling Act's intended purpose. Time will show, however, whether district cooling is widely adopted in Denmark with the applicable legislation. The District Cooling Act's legal provisions put strict limits on the behaviour of the Danish municipalities on the district cooling market. In particular, it is unclear whether the prohibition on municipal security for loans would effectively make it impossible to loan-finance otherwise economically appropriate district cooling activities. Overall, it seems to be a strange concept that municipalities will have enough power to get involved in cooling on the basis of a municipal supply task, but on the other hand will have to do this on a commercial basis. District cooling is thus an exception to the general Danish municipal law prohibiting the profit motive and trade, industry, etc. This would probably not have been necessary in order to achieve the statutory purpose of promoting energy efficient cooling of buildings. 
At first sight, it is appropriate to safeguard the consumers of municipal district heating companies against losses by cooling companies. The question is whether one does not thereby preclude the district heating companies from reaping the synergies associated with district cooling. In addition to administrative and system-technical synergies, the municipal district heating companies could also have an interest in district cooling to achieve the energy savings that district heating companies are obliged to realise, cf. the Heat Supply Act and the energysaving decree. Similarly, there is an obligation to provide consumers with information about the opportunities to achieve energy savings as well as various information about energy consumption. Why not involve district cooling in the process? Danish district cooling companies are currently not subject to similar requirements. This is in contrast, for example, with Finnish rules, (section 4 of the Finnish law 1211 of 22 December 2009 on energieffektivitetstjänster at Företag on energimarknaden [energy efficiency services from energy companies]), which cover both district heating and district cooling.

The question is whether or not the general Danish municipality rules and the opportunity to ask for municipal guarantees for utilities had given rise to a more rapid expansion of district cooling. District cooling seems to be a natural part of a modern town's energy infrastructure, and there is nothing that speaks against that town's cooling infrastructure being assimilated to the heat infrastructure in this regard.

The solution can also be defended. To make district cooling subject to the same rules as district heating would mean another sector should be subject to extensive regulation like various classic utilities in Denmark, including a monopoly on price regulation. In this view, it might not be a bad idea to start with commercial terms and associated light-touch regulation. If the market does not manage to exploit the obvious synergies, the legislature can always change course later.

For the construction of new neighbourhoods, it would be natural to consider the use of the Planning Act's common option for mandatory connection. This option has been used primarily by municipalities in connection with district heating. In the district cooling area, the powers of the Planning Act could be used to control and group new buildings with significant cooling requirements in enclaves where district cooling could beneficially be established, while other areas could be kept free of this. It should be noted that compulsory affiliation to district heating in Denmark has been subject to some criticism. Thus, it has been used to maintain the district heating customers of district heating companies whose prices have not even been able to compete with an individual boiler.

Often, compulsory affiliation to district heating brought with it a municipal guarantee package. Municipalities were thus able to use their regulatory powers through a mandatory connection to reduce their own risk of the guarantee being paid. Politicians have chosen not to give municipalities this option for district cooling.

To date, there are only a few minor district cooling plants established in Denmark, with a 12 MW plant in Copenhagen as the largest. However, there is potential, and there are plans for expansion and new plants. District cooling activities can be linked to existing municipal district heating plants and could turn out to be important instruments in Danish municipalities' growing interest in engaging in climate and energy policy. This is expressed through various initiatives that seek to reduce the use of fossil fuels within the municipal limits. In some places, there is an expressed goal of carbon neutrality. Among other things, a number of municipalities have entered into an agreement with the Danish Society for Nature Conservation to be called Climate Municipalities; this involves an annual commitment of reducing municipal carbon emissions by at least $2 \%$ for a fixed number of years [6].

\section{References}

[1] Euro Heat \& Power (2011) District Heating and Cooling. Country by Country 2011 Survey. Brussels, 98,128.

[2] Fjärrvärme, S. (2013) Varmerapporten 2013. [Heating Report 2013], Stockholm.

[3] Gammelgaard, F. (2004) Kommunalerhvervsvirksomhed [Municipality Companies], Copenhagen; Gammeltoft-Hansen, H., et al. (2002) Forvaltningsret [Administrative Law], Copenhagen; Mogensen, I. and Silic, D. (2004) Kommunalfuldmagtsreglerne [The Non-Statutory Rules about What Municipalities Can Deal With], Copenhagen; Revsbech, K. (2010) Kommunernesopgaver [Task of the Municipalities], Copenhagen: 25 et seq.; Garde, J. and Revsbech, K. (2011) Kommunalret [Law of the Municipalities], Copenhagen:11 et seq.

[4] Mortensen, B.O.G. (2006) Utilities in the Municipalities. [Kommunalforsyningsvirksomhed]. In: Anker, H.E., Olsen, B.E. and Mortensen, B.O.G., Eds., Kommunalmiljøforvaltningiretligbelysning [Environmental Regulation in the $\mathrm{Mu}$ nicipalities in a Legal Context], DJØF Publishing, Copenhagen, 77 et seq. 
[5] Mortensen, B.O.G and Gottrup, R. (2007) Kommunalvarmeplanlægningiretligbelysning [Planning Heat Supplies in a Legal Context]. DJØF Publishing, Copenhagen, 39 et seq.; Aagaard, P. and Mortensen, B.O.G. (2003) Varmeforsyningsloven med kommentarer [The District Heating Suply Act with Comments]. Thomson, Copenhagen, et seq.

[6] The Danish Society for Nature Conservation: Climate Communities. www.klimakommuner.dk 